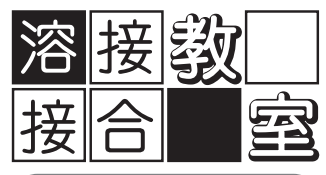

基礎を学ぶ

第 4 章 溶接施工管理

\title{
$4-9$
}

\section{溶接·接合技術の適用(自動車) ${ }^{*}$}

\section{近 藤 正 恒 $^{* *}$}

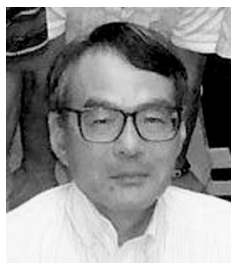

Applications of Welding and Jointing Technology (Automobile)*

by KONDO Masatsune ${ }^{* *}$

キーワード＼cjkstart自動車，ボデー，組立，抵抗スポット溶接，アーク溶接，レーザ溶接，FSW

\section{1. わが国の自動車産業の現状}

世界の自動車生産は2008年 9 月のリーマンショックを 契機とする金融危機と世界同時不況により大幅に減少し た. 日米欧の先進国の新車販売台数は一時急激に落ち込ん だが, その後のスクラップインセンティブなど各国の需要 刺激策により2010年には回復傾向になったもののその世 界的シェアは縮小しつつある. 一方新興国では, 販売需要 の回復は早く市場規模は急速に拡大している. 図 1 に主要 生産国の自動車生産台数の最近10年間の推移を日本自動 車工業会資料から示すが，日本の国内生産は 07 年のピーク 1160万台から09年 793 万台と減少した. また海外での日本 メーカの生産台数は07年に1186万台で国内生産を上回り,
今後も現地生産化拡大の傾向は変わらないものと思われ る.09年の国別生産台数を図 2 に示すが，世界で約 6000 万 台の生産の内上位 4 力国で $50 \%$ 以上を占め, 中国, 日本, アメリカ, ドイッの順番で生産台数が多い. 特に中国の生 産が急速に拡大し，06年以来アメリカに代わり世界で最大 の自動車生産国であった日本を09年初めて大幅に上回り, 様変わりの様相を呈している11.

こういった状況変化とあい俟って, 地球環境保護の観点 から地球温暖化の原因とされる $\mathrm{CO}_{2}$ 排出量を抑制するた め, 自動車燃費改善の動きや化石燃料依存度低減に向けた 取り組みが自動車産業の大きな課題となっている. 新しい 動力源として $\mathrm{HV}$ 車や $\mathrm{EV}$ 車の生産が増加しつつあり, 部 品メーカや素材メーカまで含めた産業構造の変革が今後 起こっていくものと思われる。これに伴い自動車の生産工



図 1 主要自動車生産国の自動車生産台数

*原稿受付 平成22年9月13日

**正 員 トヨタ自動車(侏) Member, Toyota Motor Corporation 
程も変わるが本項では従来の内燃機関を動力源とした自 動車，特に乗用車の生産工程を紹介することにし，HV， $\mathrm{EV}$, 燃料電池車等については次回に譲ることとする。

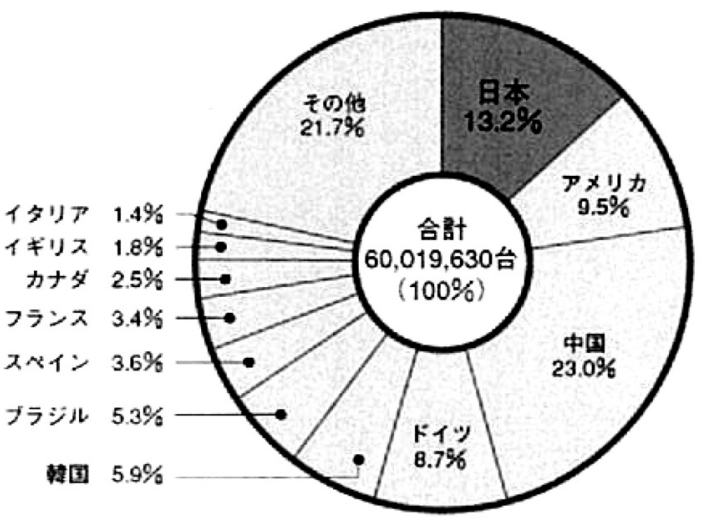

図2 2009年国別自動車生産割合

\section{2. 自動車に要求される性能と構成部材}

乗用車の外観とボデー構造の典型例を図 3 に示す2). 現 在のボデー構造の主流はユニットボデーと呼ばれる単体

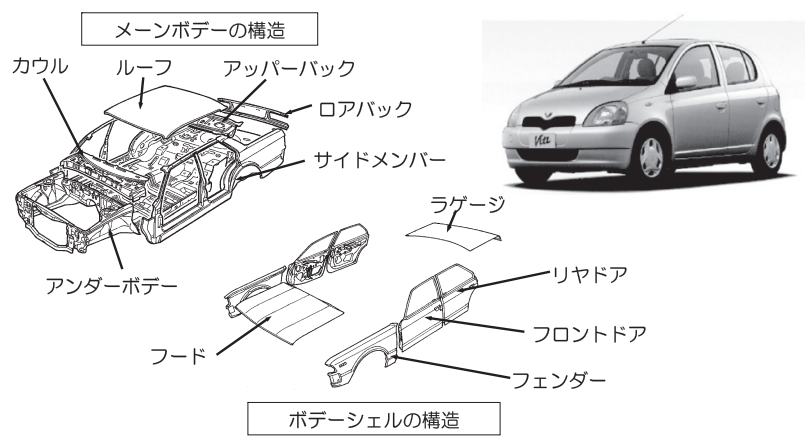

図3 自動車ボデ一構造

\begin{tabular}{|c|c|c|c|c|c|c|c|}
\hline \multirow{2}{*}{\multicolumn{2}{|c|}{ 影特生 }} & & 車 & 永 & 要 & & \multirow[b]{2}{*}{ 解品 } \\
\hline & & 張り咸性 & 的デント始 & 部财用姓 & 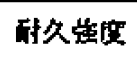 & 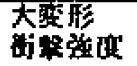 & \\
\hline \multicolumn{2}{|c|}{ 外板 } & (0) & & & $\Delta$ & & $\begin{array}{l}\text { フードフウター } \\
\text { ドフフウター } \\
\text { トランクリゥドナゥクー }\end{array}$ \\
\hline \multicolumn{2}{|c|}{ 内板 } & (9) & $\triangle$ & 0 & & & 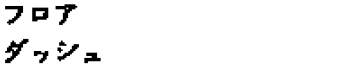 \\
\hline \multirow{2}{*}{$\begin{array}{l}\text { 部 } \\
\text { 遠 } \\
\text { 部 } \\
\text { 材 }\end{array}$} & A & & & (9) & & & $\begin{array}{l}\text { ポデーサイドメンハー } \\
\text { クロスメンバー } \\
\text { カウルボックス }\end{array}$ \\
\hline & B & & & & & & $\begin{array}{l}\text { サイドメンバー } \\
\text { デフテウントメンハー }\end{array}$ \\
\hline $\begin{array}{c}\text { 妾 } \\
1 \\
\end{array}$ & $c$ & & & & & & $\begin{array}{l}\text { ドカードパー } \\
\text { サイトメンイー } \\
\text { レインフォースシートルルト }\end{array}$ \\
\hline \multicolumn{2}{|c|}{$\begin{array}{c}\text { 茹 } \\
\text { 傮 } \\
\text { 式 } \\
\text { (法 2) }\end{array}$} & $\begin{array}{l}S \propto E^{2)}+t^{3)} \\
P_{\mathrm{b}} \propto E \cdot \mathrm{t}^{3} \\
f_{\mathrm{p}} \propto t \sqrt{\frac{E}{\rho}}\end{array}$ & $\begin{array}{l}P_{\mathrm{d}} \propto \sigma_{\mathrm{ys}} \cdot t^{2} \\
E_{\mathrm{d}} \propto \frac{\sigma_{\mathrm{ys}}^{2} \cdot t^{\prime}}{S}\end{array}$ & $\begin{array}{l}K_{\mathrm{d}} \propto E^{4)} t \\
f_{b} \propto \sqrt{\frac{E}{\rho}}\end{array}$ & $\sigma_{\mathrm{d}} \propto \sigma_{\mathrm{TS}}^{6]}$ & $\begin{array}{l}P_{\mathrm{c}} \propto 4 \\
t^{105} \cdot \sigma_{y s}^{0.5 t s}\end{array}$ & \\
\hline
\end{tabular}

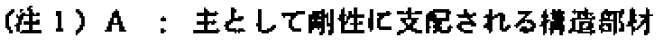

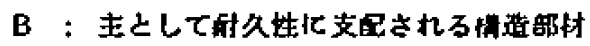

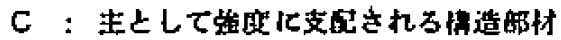

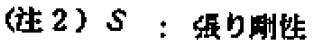

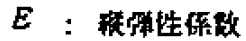

$t:$ 服度

$m$ : バネル形状による定数 $(1 \sim 3)$

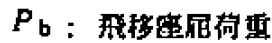

$f_{p}$ : バホルの固有玨教数

$\rho$ : 密存

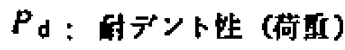

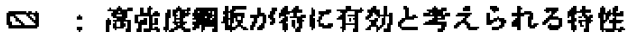

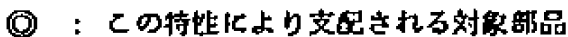

$\mathrm{O}$ :

$\triangle$ :

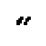

\section{中}

1) $\sigma_{p}$ : 完成新品の吽伏些さ

$E_{\mathrm{d}}$ : 付デント婊（エネルギー）

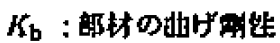

$f_{\mathrm{b}}$ : 㛃材の固有振较数

。付久强度

$\sigma_{\mathrm{TS}}:$ 引张強き

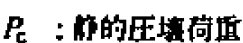


構造で, 詳細は自動車工学便覧を参照願いたい33. 基本構造 は1900年代半ばから大きく変わって抢らず，約 300～350 点の薄板プレス部品を約 $3500 \sim 5000$ 点の抵抗スポット溶 接でボデーに組み立てている。機能としては，車室空間を 形造る剛性と強度を確保するとともに, 薄板構造での長期 の耐久性を確保する防錆性能が必要で, これらの性能と燃 費向上の為の軽量化を目指した薄板化とを両立させる設 計が要求されている.

自動車ボデーの防錆性能を確保する為, 1960年代から北 米で始まった冬季の道路への融雪塩散布に対して亜鉛め っき系防錆鋼板が世界の主要な自動車でボデー鋼板とし て使われている. 亜鉛めっき系鋼板として, 日本では合金 化溶融亜鉛めっき鋼板が溶接性の良い鋼板として独自に 開発されたが, 合金化溶融亜鉛めっき鋼板であっても裸鋼 板に比較すれば抵抗スポット溶接で連続的に溶接出来る 打点数が少ない.これに関しては2008年11月に発行された 「薄鋼板及びアルミニウム合金板の抵抗スポット溶接」ゅの 詳述を参照願いたいが, 近年のボデー溶接工程での継続的 な開発課題となっている。一方軽量化に関しては軟鋼板か ら高張力鋼板に変更することによる薄板化, 鋼板に替わる 軽量代替材料としてのアルミニウム合金板の採用が進み つつある.ここで, 自動車ボデーの各部位の板厚決定要因 を図 4 に示すす. 各部位ごとに必要な特性が異なる為, それ に合わせた材料選択が肝要である. 各社が共通的に外板に アルミニウム合金板を採用し，ドアガードバー等に高張力 鋼板を採用する理由は各部位ごとの必要特性に適した材 料選択にあることが理解できる.すなわち, 材料を適材適 所に使い分けるマルチマテリアルのハイブリッド構造が, これまで鋼板のみで主に作られてきたボデーにおいて必 要となっている.

\section{3. 自動車に使われる材料と接合技術}

図 5 に自動車全体の材料構成を重量比で 60 年代からの 推移として示すの. 従来は圧倒的に鉄系材料の使用割合が 多く約75\%を占めていたが, 現在ではアルミニウム合金を 中心とした非鉄と樹脂部品の比率が 03 年のトヨタクラウ ンでみると, 重量全体の $26 \%$ に占めるまでに高まってい る. 割合は車種によって異なり, 鋳鉄製のエンジンブロッ クで出来たエンジンを搭載する小型車のヴィッッでは車 全体が軽量であることもあり, 現時点でも鉄系の比率が高 い.この図は重量比である為, 軽量材の採用が変化量とし ては少なく見えるが, 近年では多くの部品が鉄系材料から 軽量材料である非鉄, 樹脂へ変更され, 軽量化が着実に進 んでいる。前項で述べたように, 自動車の各部位で必要な 特性が異なるため, 今後は各部位ごとに最適な材料の採用 が設計的に要求される。しかし, 自動車という製品の構成 部材としては出来るだけ一体部材の方が最終的に組立て 易いことから，一体化の為にそれぞれの材料を繋ぐ，溶 接・接合技術が重要になる。材料技術は日々進化しており, マグネシウム合金, CFRP 等の軽量材料だけでなく, 多様 な材料が今後の $\mathrm{HV}, \mathrm{EV}$, 燃料電池自動車には使われると 考えられており, それらを使いこなす接合組付け技術の開 発が最重要課題として注目されている.

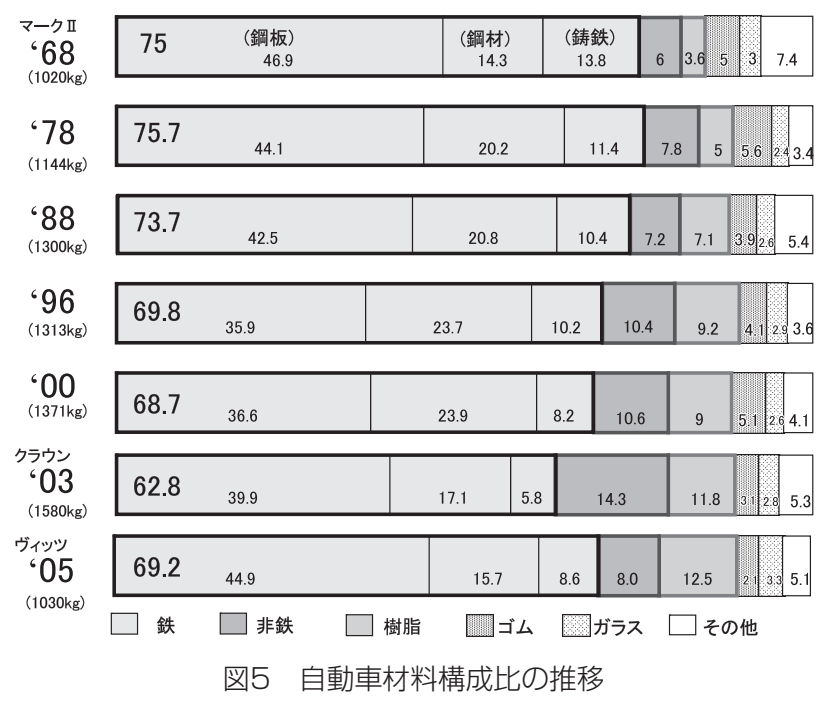

\section{4. 自動車ボデー組付け工程概要}

自動車ボデーの組付け工程概要を図 6 に示す》。大きく 分けてエンジン, 駆動系, シャシ部品を取り付けるベース となるアンダーボデー, 車室の両側となるサイドメンバー を組み合わせて骨格のメーンボデーを組み立て，それらに シェル部品と呼ばれるドアー, フード，ラゲージ等の外板 蓋物部品をボルトで組み付けることにより塗装前のホワ イトボデーとなる。まず数十点のプレス部品を集合させ, 小サブアッセンブリーと呼ばれる, 例えばエンジンコンパ ートメント, フロントフロア, リヤフロア等のパーツ部品 を作る.これらの小サブアッセンブリーはメインラインと は離れた場所又は外注部品メーカで生産されることが多 い.これらの小サブアッセンブリーをメインラインの近く に運搬し，メインラインへ投入する単位部品，例えばサイ ドメンバーファイナル, アンダーボデーファイナル部品を 作る。最後にロボットを多数台配置した連続的に搬送され るメーンボデーファイナルに投入し, 多数の抵抗スポット 溶接を実施し，剛性と強度を兼ね備えたボデーを完成させ る.

このようなボデーの製造工程はボデー製造メーカ各社 で夫々特徴があり, 海外メーカでは連続的にボデーを搬送 するライン方式ではなく，AGV 台車に載せたボデーを並 列式のステーションに搬入して組付ける図 7 に示すロボ ゲート方式も取られている。ここで，日本でのボデー組付 け方式の変遷を概略紹介する。

まだ多くの生産を人手に頼っていた1960年代では, 図 8 に示すように各ステーションで, 人が治具内にプレス品を セットし, 手動でポータブル式溶接ガンを操作し抵抗スポ ット溶接によるボデー組付けを実施していた。当時の工場 の様子を図 9 に示す.このステーショナリ方式の生産性を 向上させる為, 1970年代にループ状にライン化を図ったも のが図10に示すループ方式で, 治具台車を車種ごとに造る ことにより，いろいろな車種をひとつのラインに投入でき る, 多車種混流生産を可能にした。 これを発展させ大規模 な生産ラインとしたものがゲートトラック方式で1970年 代後半には 1 分夕クトで多車種の生産に対応するこの方 


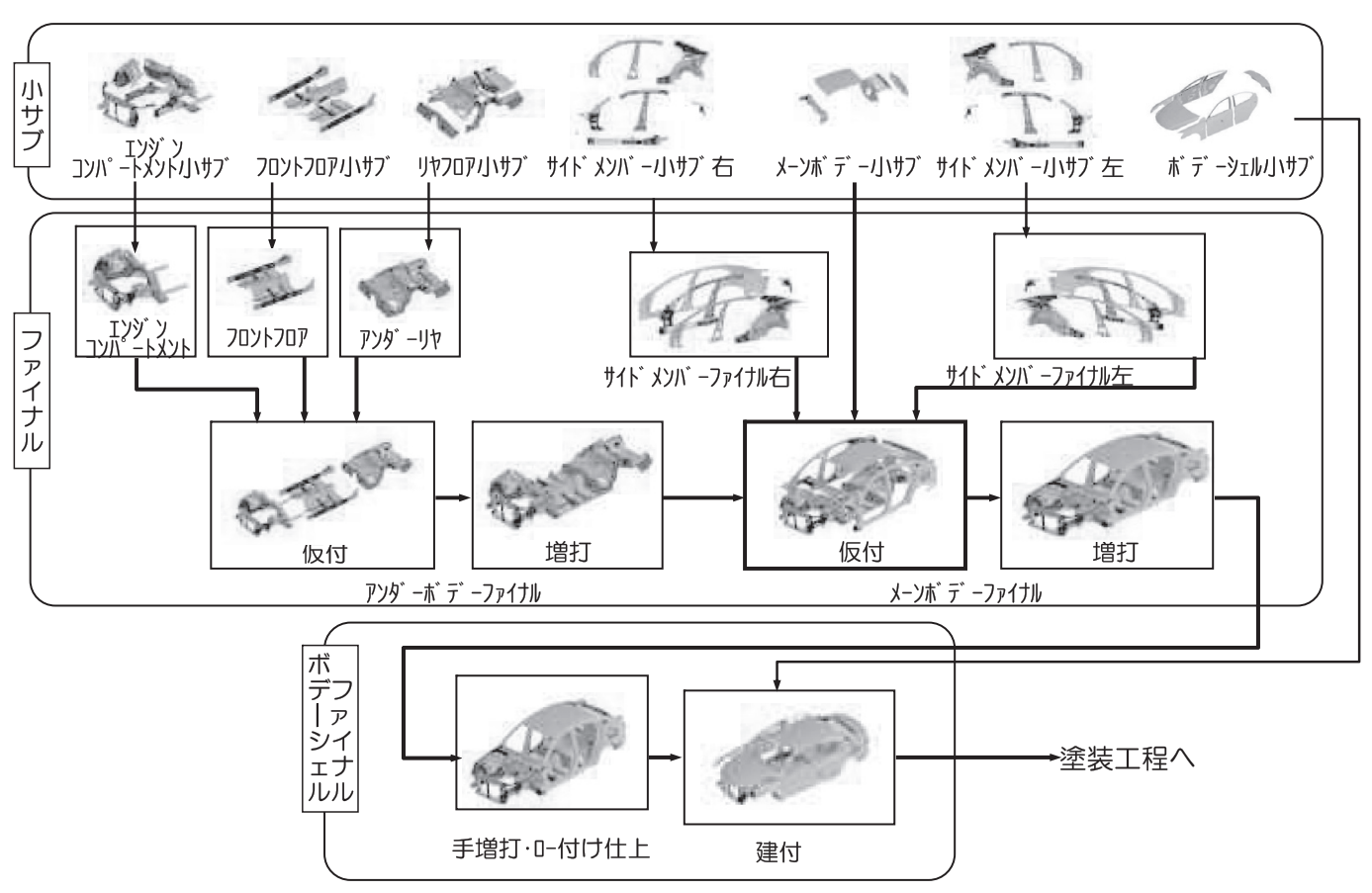

図6 ボデ一組付工程

仮付工程

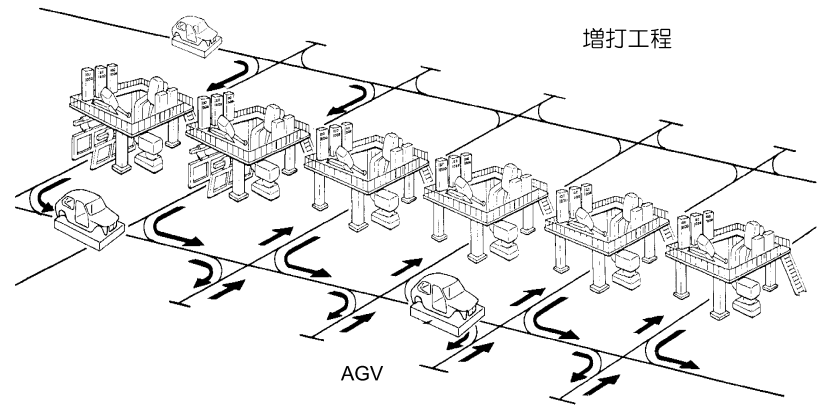

図7ロロボゲート方式

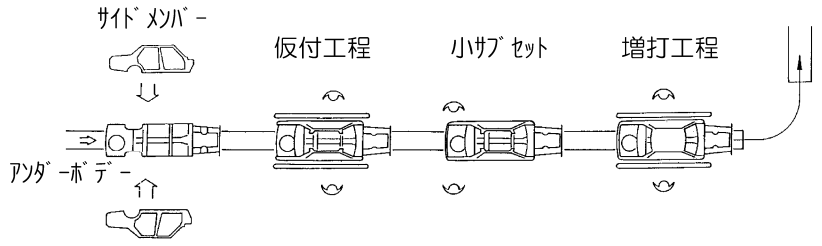

図8 ステーショナリ手動溶接方式

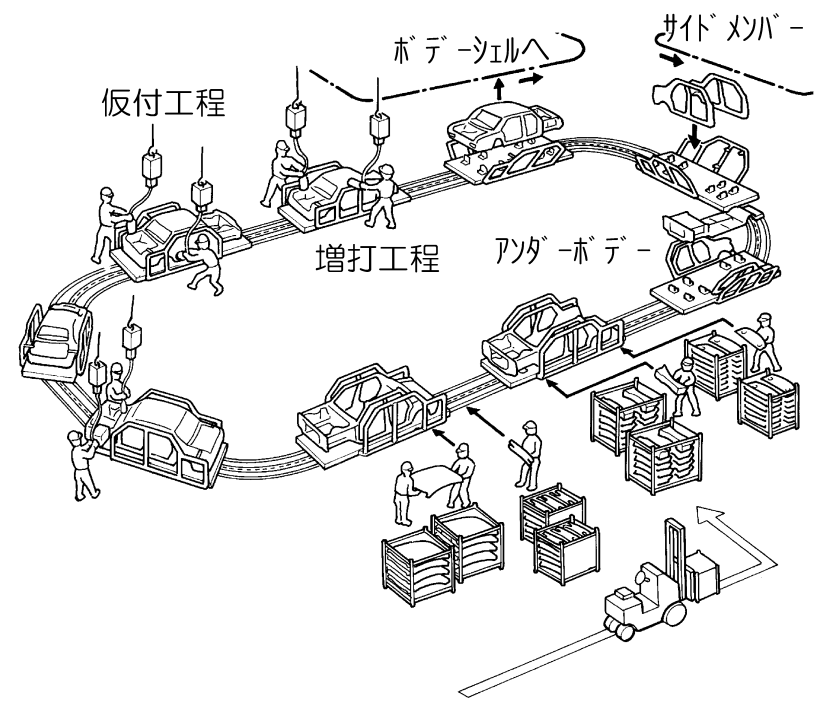

図10 ループ方式

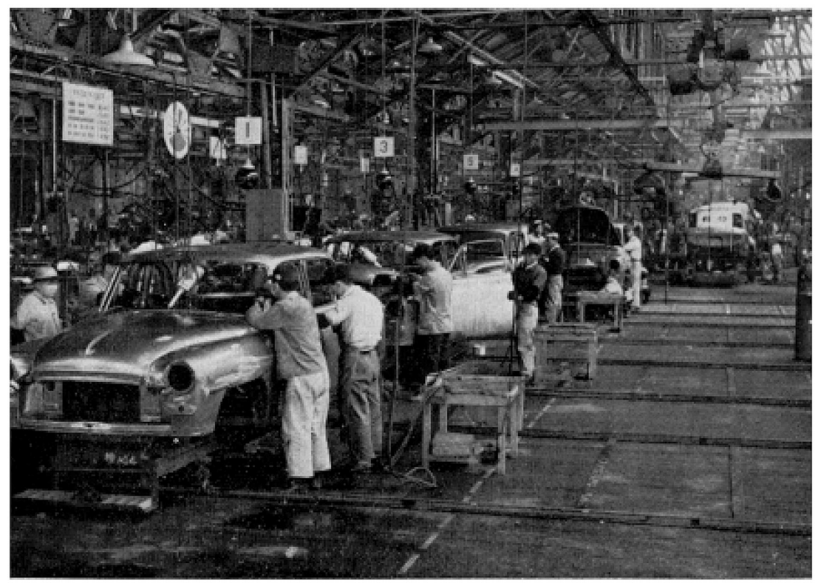

図91960年代のボデー工程

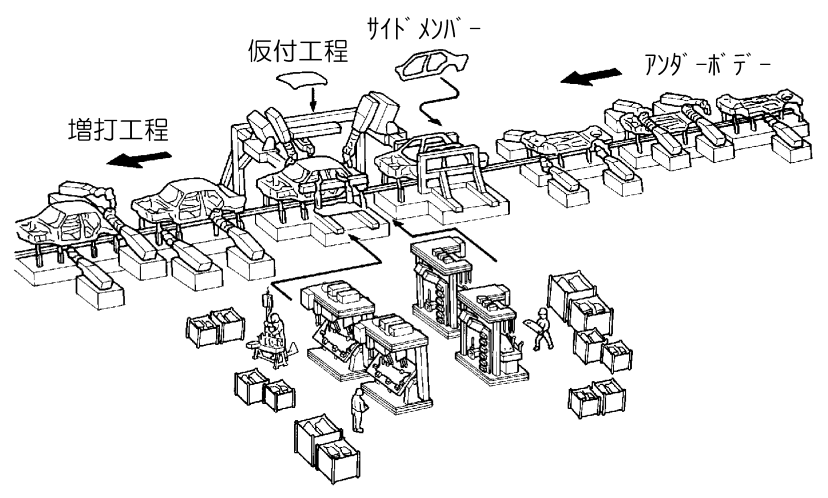

図 11 マシンバック方式 


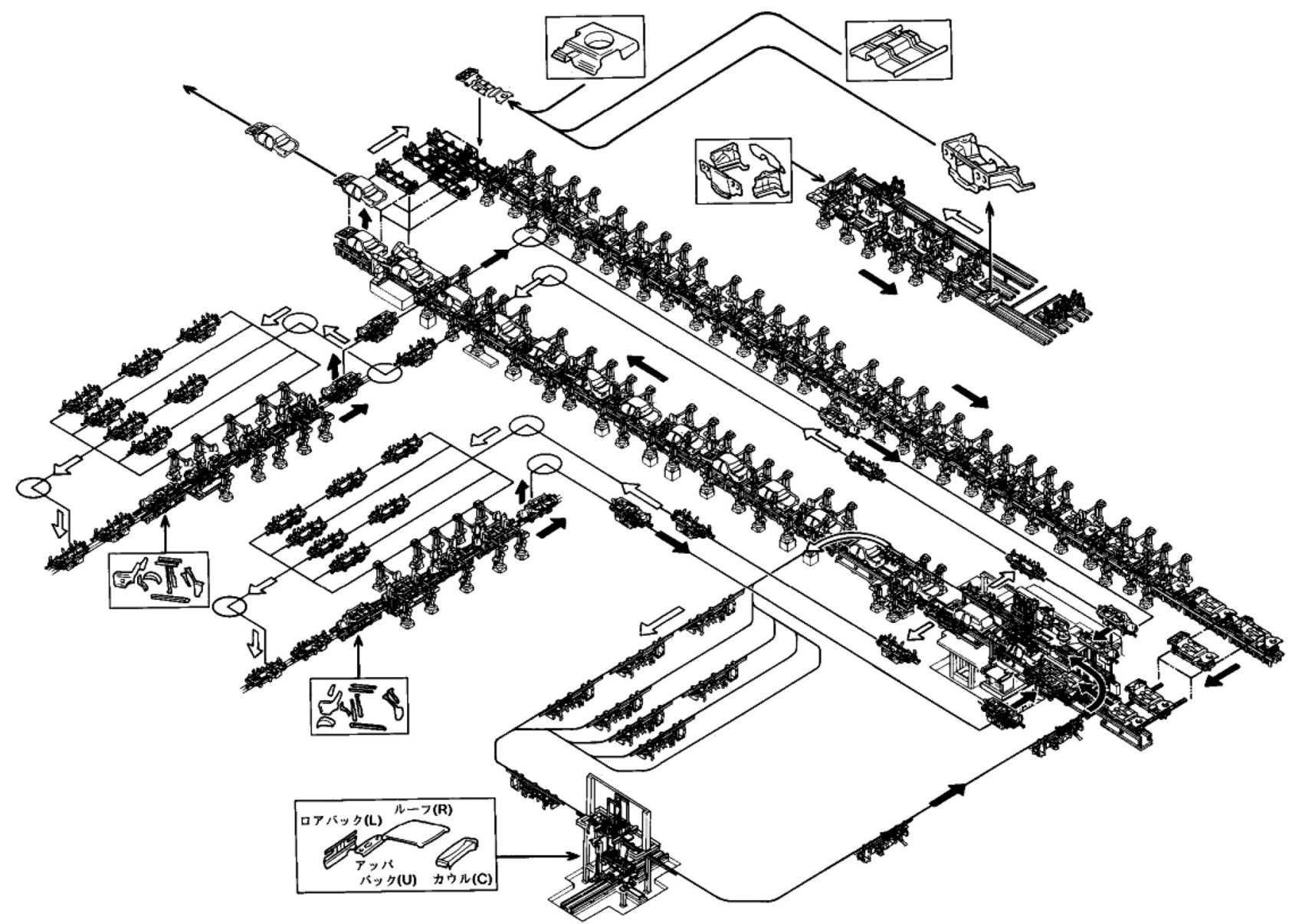

図12 FBL 方式

式の生産ラインが各社で構築された. しかし, この方式は トラック台車とゲートの組合せが 1 車種で多数出来てし まうことから，1車種でのボデー組付け精度のばらつきが 発生しやすい. そこで 1 車種の組付けは単一治具で実施す るようにし，ボデー精度の安定化を図った図117に示すマ シンバック方式に1980年代に移行した.マシンバック方式 は 1 車種ごとに専用組付け治具があることから精度確保 は容易であるが, 多車種を一つの治具で組付けることは困 難で, ラインの多車種対応とボデー組付け精度の確保を両 立させる方式が必要となった。この要望に答える方式とし て，トヨタでは1985年に図12に示す FBL（Flexible Body Line）方式を開発し, 多車種を生産出来る汎用ラインとし て世界中の工場に設置した7. 現在ではこの FBL 方式の発 展形として, 車種ごとに必要な搬送パレット, 治具を簡略 化した GBL (Global Body Line) 方式がボデー組付け方式 としてトヨタでは一般的に使われている.

\section{5. ボデー組付け工程に主に採用されてい る接合技術}

1) 抵抗スポット溶接

プレス部品をボデーとして一体化する組付け技術には, 生産コストが安価なことから主に抵抗スポット溶接が使 われる場合が多い。通常の自動車ボデー溶接ラインでは, 図13に示すポータブル式の溶接機が使われる.溶接機の電 源としては図14のような各種方式があるが, 最近では図 15
に示すインバータ方式が日本では採用されている4. 従来 の図13に示したガン・トランス分離型の交流通電方式で は, 工場送電の高電圧から架台に取り付けた交流トランス で溶接電圧に降圧し，ロボットに搭載した溶接ガンとの間 を二次ケーブルで連結する。この際トランス二次側は大電 流通電の為, 必要なケーブル径が太くなり, ロボットの動 きがこのケーブルで制約され且つその動きからケーブル が破断する不具合が多かった。 それに対しインバータ方式 は一次側で直流化した後高周波交流に変換する為降圧卜 ランスを小型化出来, 溶接ガンと一体化しロボットに搭載 が可能である.この方式では電源とトランス付き溶接ガン を繋ぐ一次ケーブルが低電流であることにより細く出来 る為, ケーブル切断不具合が無くなるメリットからロボッ 卜溶接工程で急速に普及した. 本方式は二次側で再度整流 し, 溶接ガンのふところ深さで決まる交流回路でのインダ クタンスに左右されない直流で溶接されることが多い. 直 流溶接では溶接電極が連続溶接打点に伴い+側では凸状 に一側では凹状に変形することが知られているが, 実用上 は電極変形が連続溶接性に及ぼす影響は少なく, 従来の交 流溶接とほぼ同等である ${ }^{8}$.

溶接設備での最近のもうひとつの大きな変化は溶接ガ ンの加圧方式の電動化である. 従来抵抗スポット溶接の電 極加圧には空圧又は油圧が使われてきた.これを図16に示 すように AC サーボモータの電動加圧式に置き換える溶 接ガンが1995年頃から導入された. 本方式の詳細は参考文 献9, 10)を参照願いたいが, 図17に示すようにロボットと溶接 


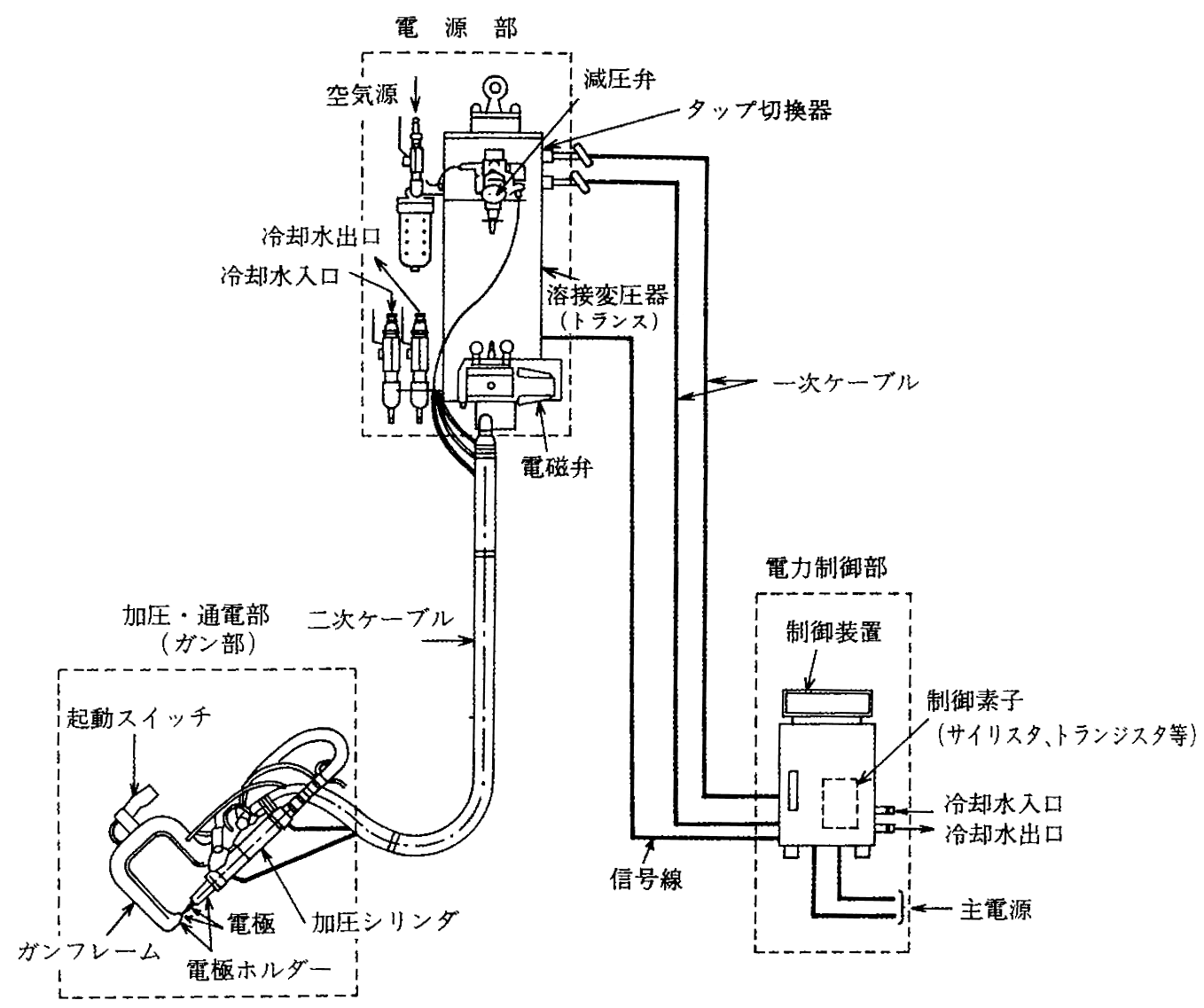

図13 抵抗スポット溶接機の構成

\begin{tabular}{|c|c|c|c|c|c|}
\hline \multirow{2}{*}{\multicolumn{2}{|c|}{ 榞方式 }} & \multirow{3}{*}{$\frac{\text { 定置形 }}{0}$} & \multicolumn{2}{|c|}{ ポータフル形 } & \multirow{3}{*}{ 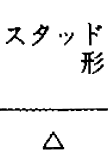 } \\
\hline & & & \multirow{2}{*}{$\frac{\text { 分蜼形 }}{0}$} & \multirow{2}{*}{$\frac{\text { 一体形 }}{0}$} & \\
\hline 交 & 単相交流式 & & & & \\
\hline 式 & 三相纸周波式 & 0 & $x$ & $x$ & $x$ \\
\hline \multirow{3}{*}{$\begin{array}{l}\text { 直 } \\
\text { 流 } \\
\text { 式 }\end{array}$} & 単相整流式 & O & 0 & $x$ & 0 \\
\hline & 三相整流式 & $\mathrm{O}$ & $x$ & $x$ & $\Delta$ \\
\hline & インバータ式 & 0 & 0 & 0 & O \\
\hline \multicolumn{2}{|c|}{ コンデンサ式 } & O & $x$ & $x$ & $x$ \\
\hline
\end{tabular}

○：好ましい組合せ

$\triangle$ : 好ましくないが, 可能な組合せ $\times$ : 好ましくない組合せ

図 14 装置構成亡電源方式の組み合せ

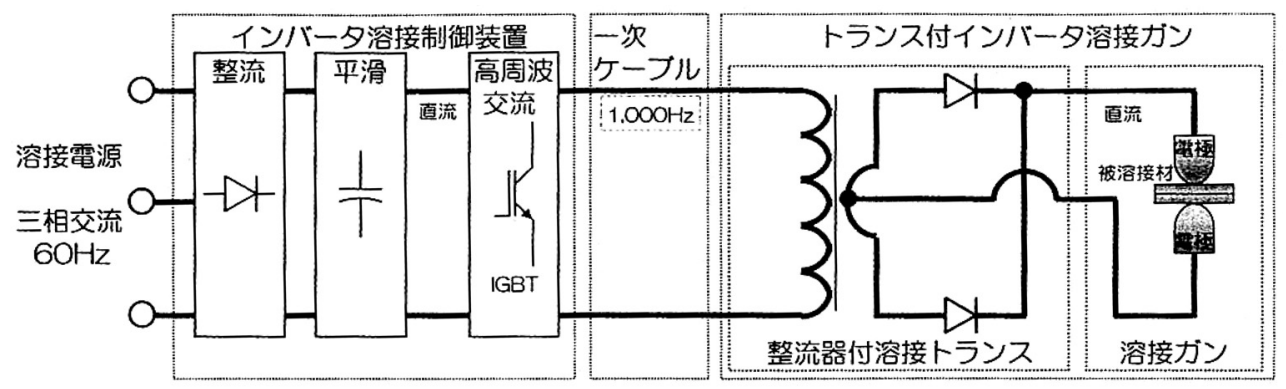

図15 インバー夕溶接機の設備概要 
ガンの協調制御によりロボットの移動中に溶接ガンの開 放ストロークを任意に保ち, ロボットが打点位置に来た時 に直ぐに溶接動作に入れることから一定時間内にスポッ
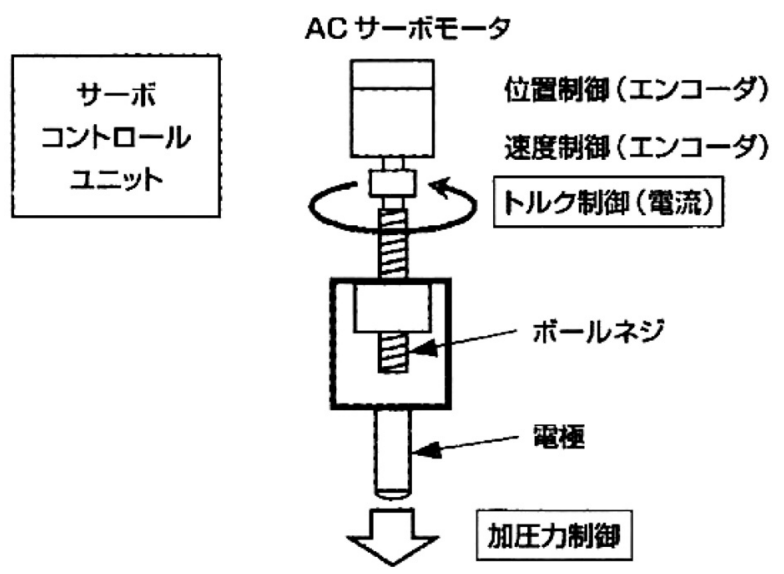

図 16 電動加圧式ガンの構造と制御
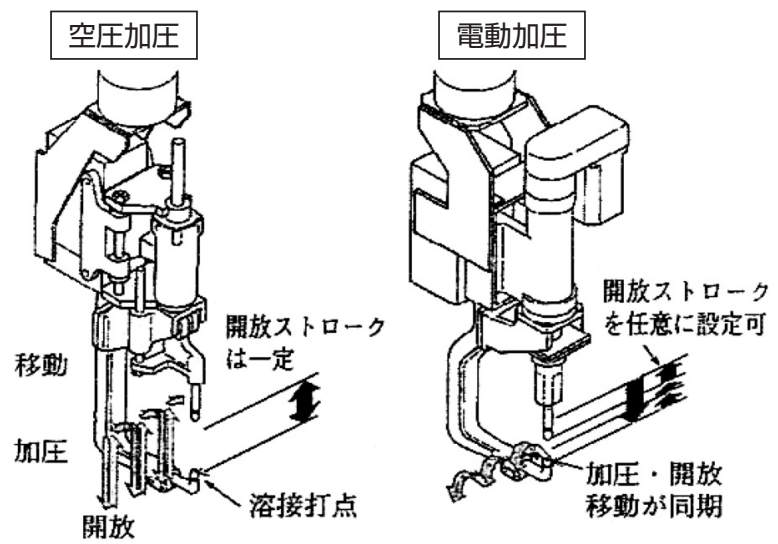

図 17 空圧加圧式と電動加圧式ガンの動作比較
卜溶接出来る打点数を増加出来る. 生産性を極限に高めた い量産ラインには必須技術になっている.

最近では溶接現象のシミュレーション技術の進歩によ り，抵抗スポット溶接の発熱や，継手近傍の変形を予測す ることが可能になった．1961年に Greenwood によって始 まった抵抗スポット溶接のシミュレーション技術は今日 では例えばSwantec 社のソフトウェア Sorpas として市 販されている。しかし，単に溶融部径（ナゲット径）を推 定出来るだけでは実用上の効果は少なく, 実際の溶接現場 での品質モニタリング, 溶接条件のアダプティブコントロ ールに応用出来ることが重要である. 連続溶接中の電極先 端形状の変化, すなわち通電径を溶接中のモニタリングデ ータからナゲット径のシミュレーションに組み込むハイ ブリッドシミュレーション技術の実用化に期待したい ${ }^{111}$.

抵抗スポット溶接の品質モニタリング技術の実用度が 低い現状から, 出荷品質の最終検査法として従来からの図 18に示すたがねチェックが使われている4. しかし，高張力 鋼板をたがねチェックすると，それにより母板へのきれつ を誘発する危険性が指摘され，前述したようにボデーに高

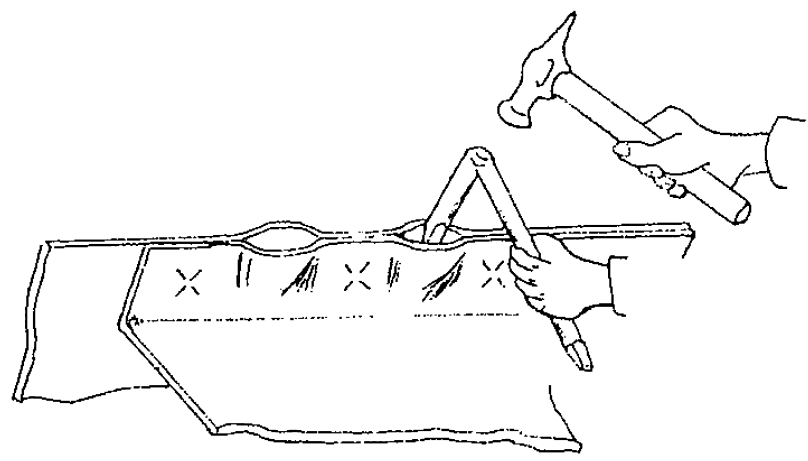

図18 たがね破壊チェック

\begin{tabular}{|c|c|c|c|c|}
\hline \multirow{2}{*}{ No. } & \multirow{2}{*}{ スポット品質検査方法 } & 検 查 内 容 & 概 要 & \multirow{2}{*}{$\begin{array}{l}\text { “品質判別" } \\
\text { 信 頼 性 }\end{array}$} \\
\hline & & 特 & 図 & \\
\hline 1 & 目 & $\begin{array}{l}\text { スポット打痕焼け具合より, ナゲット } \\
\text { 径の大小を判断する。 }\end{array}$ & & $x$ \\
\hline 2 & $\begin{array}{c}\text { タガネハナレチェック } \\
\text { (破壊) }\end{array}$ & $\begin{array}{l}\text { 打点近傍にタガネを打ち込み, ハナレ } \\
\text { の有無またはナゲット径の大きさを測 } \\
\text { 定する。 }\end{array}$ & 代溉定 & 0 \\
\hline 3 & ナゲット断面チェック & $\begin{array}{l}\text { 特に正確なナゲット径, ナゲット内性状 } \\
\text { (ブローホール, バクヒ等)を知る目的で } \\
\text { 打点中心線より細片カッティング切出し } \\
\text { 後, 樹脂埋込みー研磨 }\end{array}$ & 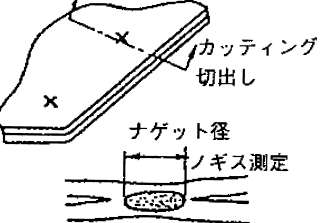 & (1) \\
\hline 4 & $\begin{array}{l}\text { 非破壊険查法 } \\
\text { (超音波探傷) }\end{array}$ & $\begin{array}{l}\text { ボデー(含む 部品)を全く傷つけること } \\
\text { なくナゲット径の大きさを判別する。 }\end{array}$ & $\Longrightarrow$ 音波探伤子 & $\Delta$ \\
\hline
\end{tabular}

図19 スポット溶接品質の検査方法 


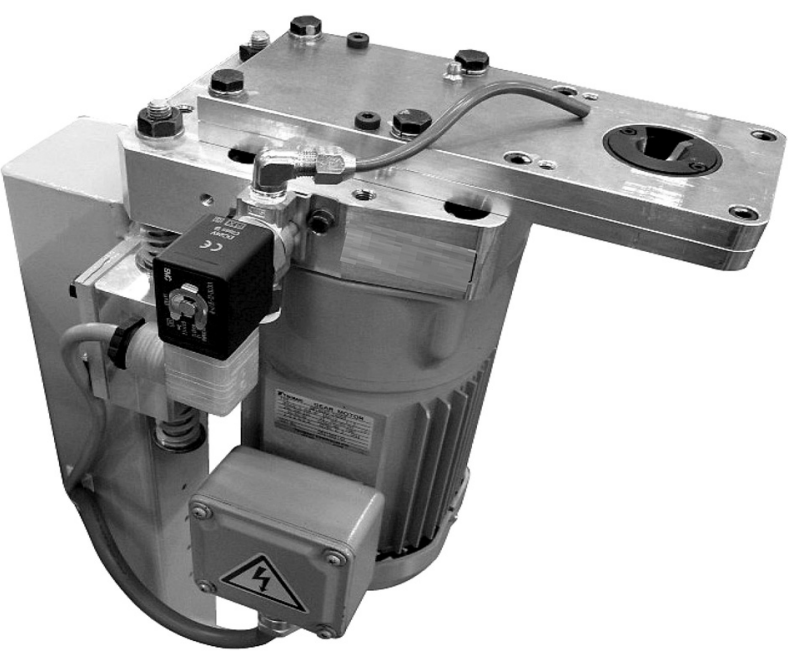

図20＼cjkstart電極チップドレッサーの例

張力鋼板の採用が拡大しつつある背景から, 図19に示した 超音波探傷法に代表される非破壊検査法の採用が検討さ れている》。. 大量の溶接打点を短時間に確実に検查する実 用化技術の確立が望まれている。

ボデーの防錆性能向上の為亜鉛めっき鋼板が採用され て以来, 被溶接材めっき亜鉛と抵抗スポット溶接の電極主 成分の銅が合金化し, 電極が変形することにより先端径が 拡大し, 一定電流で連続的に溶接出来る打点数は大幅に減 少した ${ }^{12}$. これに対し亜鉛と合金化し難い電極材料や電極 表面処理等いろいろな夫が従来から試されてきたが，コ ストに見合う方策は未だ見つかっていない. 最近では変形 する電極を初期の形状に戻す方策の検討が逆に進み, 図20 に示すような電極チップドレッサーを設置する工程が増 加している。この装置はロボットが一周期の仕事を終了 し, 原点位置に戻った時に上下の変形した電極を初期形状 化する。これにより電極先端形状を常に一定に保ち, 連続 打点に伴う電極先端径の拡大に連動した溶接電流值のス テップアップ等の電流值を増加させる制御を省略するこ とが出来つつある.

\section{2) レーザ溶接}

自動車生産へのレーザ溶接の適用は $\mathrm{CO}_{2}$ レーザの黎明 期である1980年代に電子ビーム溶接に替わってミッショ ンギヤに適用されたものが最初と思われる。 その後1985年 にトヨタがプレス加工前の素材結合／テーラードブラン ク工法に採用した. 図21に実用化したボデーサイドパネル アウタ用結合素材を示す13. 1990年代に入ると設備維持管 理がガスレーザに比べて容易な固体 YAG レーザの大出 力化が進み, 光ファイバーによる伝送方式と合わせてロボ ットに出射光学系を搭載したシステムとしてボデー溶接 ラインに導入された。 1996年に Volkswagen がルーフとサ イドパネルのシーム溶接に実用化し，1994年には Opel が トランクリッドの溶接と切断に採用した。またアルミニウ ム合金板製ボデーにも全長で $30 \mathrm{~m}$ のレーザ溶接が AudiA4 で採用されている. 現在 Volkswagen の Touran と Golf Vでは車体当り全長 $70 \mathrm{~m}$ のレーザ溶接が適用さ れている ${ }^{14}$ 。レーザ溶接はスポット溶接に比較して溶接継 手に必要なフランジ長さが短く出来, またスポット溶接に

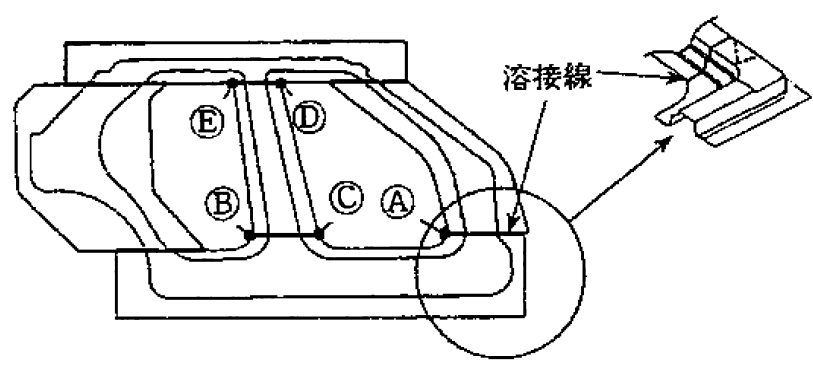

図21 サイドパネルアウタ用結合素材

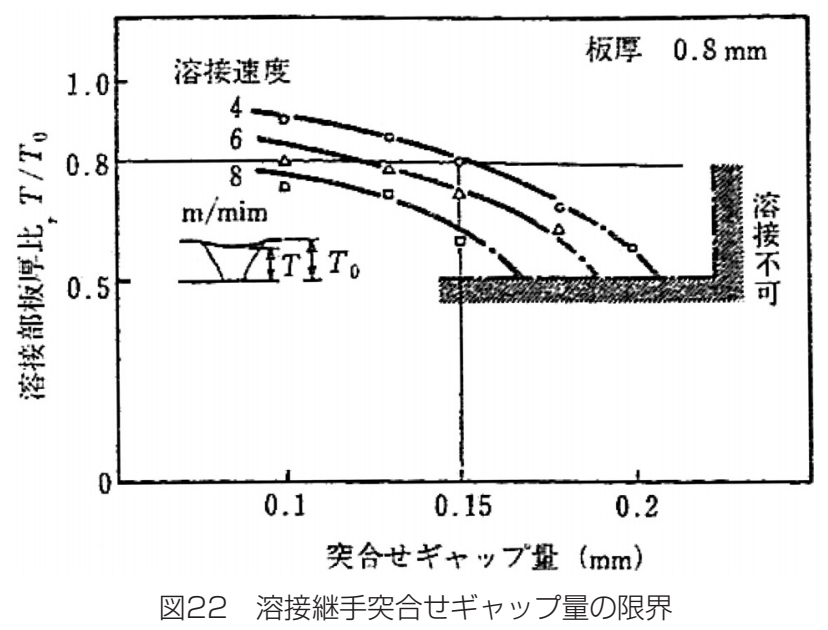

比較して連続溶接のメリットもある. しかし日本では初期 投資額が高いこと，プレスパネルの隙間管理が厳しいこと から, まだ適用車種が限られている. 図 22 に示す例では, 溶 接速度が $4 \mathrm{~m} / \mathrm{min}$ の場合溶接部板厚比を $80 \%$ 以上確保す るには突合せ隙間量は $0.15 \mathrm{~mm}$ 以下が必要となる ${ }^{13)}$. 特に 適用拡大を阻害している隙間に対する良品条件範囲を広 げる為に,アーク溶接とのハイブリッド溶接化の工夫やレ ーザブレージングの検討も進められている. 今後抵抗スポ ット溶接の生産コストを下回り適用部位を拡大する為に, より安価で小規模設備であるファイバーレーザや，遠距離 からレーザをスキャン照射し，すばやく溶接点を移動出来 る為生産性の高い, リモートレーザの採用 ${ }^{15}$ が検討され拡 大していくものと思われる.

\section{3) 摩擦摫拌接合 (FSW)}

摩擦攪拌接合は英国の TWI によって1991年に特許出願 された比較的新しい接合法である.自動車部品への日本で の適用は2001年にアルミニウム合金製サスペンションア ームへ採用されたことが報告されている.ボデー部品に対 しては2008年に燃料電池自動車のアルミニウム合金製サ ブフレームへの採用が報告されているが，これらの適用例 の連続接合に対し，自動車では点接合 (FSSW) としてア ルミニウム合金板のドアー他外板蓋物部品に採用される ことが多い. 図23に FSSW の工程説明図, 図24にその溶接 部断面を示す ${ }^{16}$. 2004年にマツダの RX-8 リヤドアへの採 用例が報告されているが, 外板へのアルミニウム合金板の 採用拡大に伴い，日本では自動車各社が標準工法として採 用するに至った。最近ではボデーシェル部品のラゲージで 鋼製ボルトとアルミニウム合金板の異材接合に採用され るなどアルミニウム合金板を対象にした，品質安定性の高 
(a) Plunging

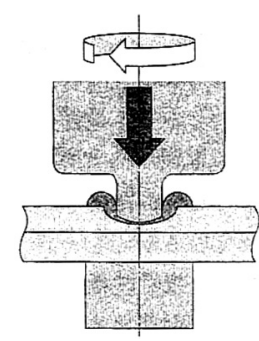

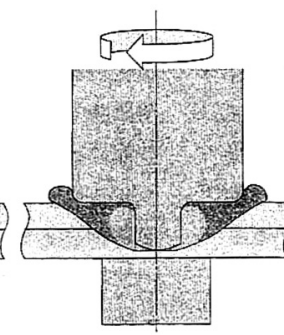

(b) Stirring

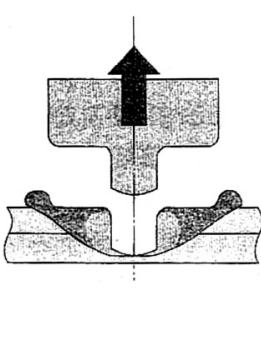

(c) Drawing out
図23 フリクションスポット溶接の工程

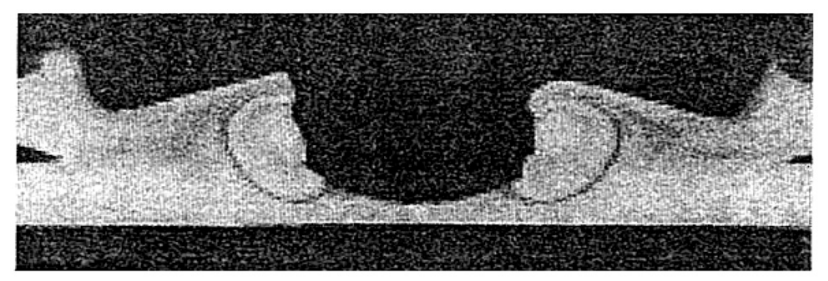

図24 フリクションスポット溶接部断面

い接合法として普及が進んでいる ${ }^{17}$. 本技術は摩擦攪拌ツ ールの耐久性が課題であり, 鋼板への FSSW の適用拡大 に向けて，この課題の解決が期待されている.

\section{6. ユニット部品組立工程に主に採用され ている接合技術}

自動車の構成部材としてボデーの他に図25に示す主要 な部材がプレス部品を溶接して組立てられ, 完成車組立て ラインヘユニット単位で組付けられる部品として供給さ れている.これらのユニット部品に使われる溶接技術と生 産工程を代表的な部品で紹介する.

\section{1) アーク溶接}

自動車の骨格部品でエンジンや駆動系部品を搭載する フレーム, タイヤが取り付けられるリヤアクスルや振動を 吸収するサスペンション部品はボデーと同様, 板プレス品 を溶接で一体化組付け, 製品とする構造が取られる場合が 多い. しかし使われる板厚がボデーに比べ厚く, 高い剛性 強度も必要な為, ボデーで多用される抵抗スポット溶接で はなく連続溶接のアーク溶接を採用することが通常であ る. 構造の例として図26にレクサス系リヤサスペンション メンバーを示すが, パイプと板プレス品の組付けで, 部品 点数 45 点, アーク溶接長さ約 $8.1 \mathrm{~m}$ である. 板厚が $3 \mathrm{~mm}$ 以下の場合は防錆能力の高い亜鉛めっき鋼板, それ以上は 裸鋼板が使われる場合が多く, ベース鋼板には高張力鋼板 が主に採用されている。

適用されるアーク溶接法として旧来は造船・建築等厚板 部品と同じ $\mathrm{CO}_{2}$ アーク溶接で, 溶接ワイヤが母材と短絡し て溶融移行する電流領域が用いられていたが, 近年では薄 板に対する良品条件範囲の広い MAG（Ar80\%-CO $\left.\mathrm{CO}_{2} 20 \%\right)$ アーク溶接が日本では普通となっている.アーク電源がイ ンバー夕化され制御速度が速く出来るようになったことか らいろいろな電流波形が工夫されているが, 1 パルス 1 溶 滴移行の中周波数パルス溶接が基本電流波形である. 溶接 ワイヤを送給しワイヤからアークを出す, GMA 溶接の課

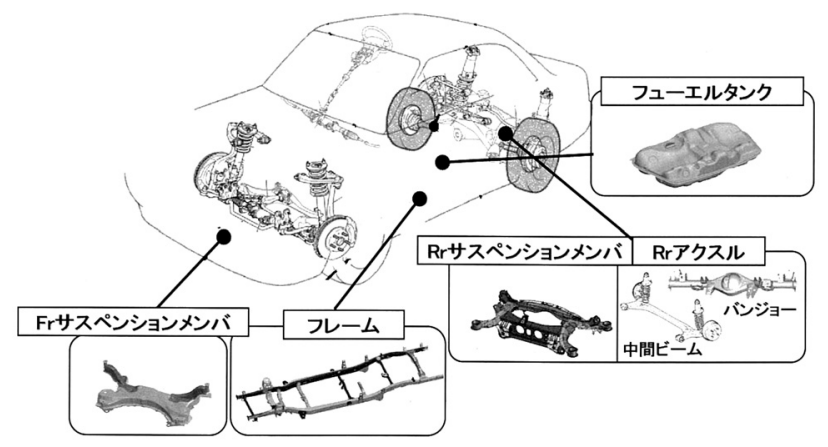

図25 自動車の主要な板金構造のユニット部品

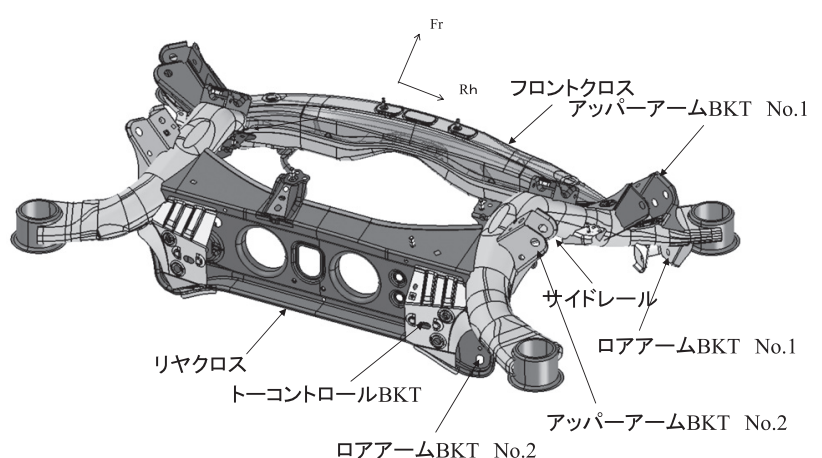

図26 リヤサスペンションメンバの構造例

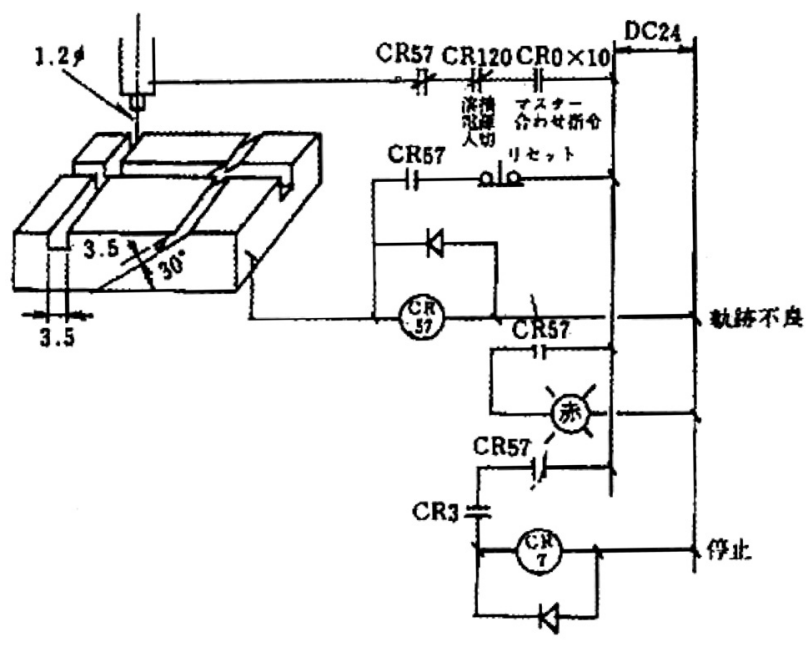

図27溶接ワイヤずれ検出ゲージの例

題であるスパッ夕を低減する試みが最近では進みつつあ る ${ }^{18)}$.これに関し溶接ワイヤの送給モータに $\mathrm{AC}$ サーボモ 一夕を採用することにより, 溶接ワイヤの送り制御を精密 に行い, 電流制御と合わせた総合制御が可能になっている. この技術は低電流短絡移行の領域でスパッ夕を減らすこ とが可能で薄板のアーク溶接に適用範囲が広い. 現在では これらのアーク溶接技術の進歩によって, 溶接トーチをロ ボットに搭載し自動溶接するアーク溶接では無人化が進 みつつあるが, 完全無人化には品質検査の自動化が今後の 課題である.アーク溶接工程で溶接ビードの溶达み品質を 決める大きな因子としてワークへの溶接ワイヤ狙いずれ がある.最近の自動溶接工程には図27に示すような検出ゲ ージが設置されることが多く，ワイヤ位置を監視すること により，一定の品質が確保できる工夫がなされている ${ }^{19}$. 


\section{2) 抵抗シーム溶接}

自動車のフュエルタンクは欧米では樹脂製が多い。日本 においても量産車用は樹脂製へ素材転換が進みつつある. しかし，樹脂製は成形設備や型への投資額が高額な為, 少 量生産の 4 輪駆動車用や多種少量生産工場向けには鋼板 製が引き続き採用されている.これに使用される鋼板は最 近の内燃機関用燃料の多様化に対応し，製品の防錆性能確 保の観点から，耐食性に優れた $\mathrm{Sn}-\mathrm{Zn}$ めっき鋼板や $\mathrm{Al}$ 系 メッキ鋼板が使われる. その為, 抵抗溶接性が裸鋼板に比 べて著しく悪く, 溶接条件の維持管理が重要である. 製品 構造としては薄鋼板のプレス品のアッパーとロアパネル を外周でシーム溶接し一体化する.この外周溶接に抵抗シ 一ム溶接を用いるが, 溶接機の電極輪で挟んだワークを回 転駆動させつつ, 電極輪の軌跡を常に外周に沿わせる特殊 なアイアンマン治具を従来は付設していた。しかしこの治 具は形状が異なる種類ごとに専用であり, 多種類対応が困 難な為, 近年ではロボットがワークを把持駆動し, 上下の シーム溶接電極輪は挟むだけで駆動しない, 図28のような ロボットシーム溶接システムが実用化されている. シーム 溶接に使用される溶接電源は最近では抵抗スポット溶接 と同様なインバー夕方式で, 直流溶接ではなく一定周期で 極性を反転する交流矩形波で溶接を実施する場合が多い. 交流溶接化により直流溶接時にプラス極とマイナス極で 発生する電極変形の異形化と生成する溶融ナゲットの極 性による生成位置の偏りを防止する。

\section{3) 電子ビーム溶接（EBW）}

自動車の駆動系トランスミッションのギア類では高強 度の継手が必要で, 長い継手長さに対応出来る深溶け込み の電子ビーム溶接が適用されてきた. 1980年代初めに真空 を必要としないレーザ溶接への転換が一時進んだが, EBW で用いられる電子線は磁気制御が容易で, 予熱, 後熱 処理を可能とする熱源分散やビード位置, 溶け込み形状を 制御出来る為, 近年でも採用されている. また, EBWで必 要な真空引き時間を短縮する為, 被溶接物を予めカセット 内に収め, そのカセットを循環させて溶接するカセット式 $\mathrm{EBW}$ 機も開発され生産性の向上に寄与している. EBW を適用したギア類のような強度部品では溶接部の全数検 査が実施される。検査は継手線が完全に溶かされ無くなっ ていることをチェックする目的で, ワーク全体を水中に沈 め超音波の探触子で継手線からの反射波が無いことを検 査している。

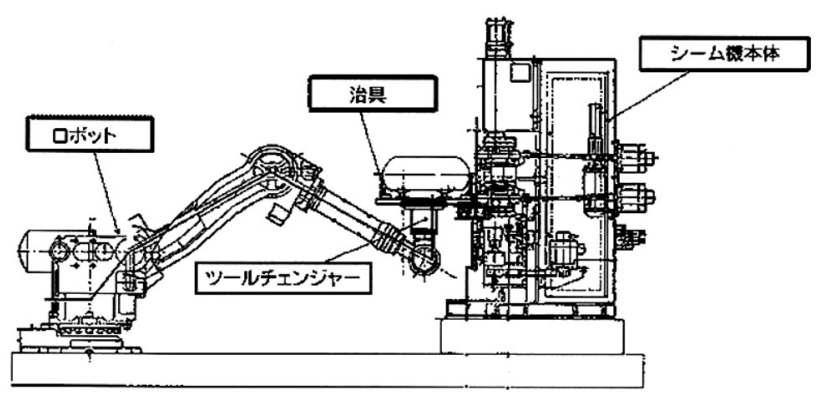

図28ロロボットシーム溶接システム

\section{7. あとがき}

自動車は約 30,000 点の部品で構成されている.乗員用の シート, タイヤ, 空調用のエアコンといった大物部品から, ボルト，ナットなどの小物部品まで多種多様の部品があ り, 溶接・接合技術が使われている部品も多い.今回はそ の中で, 板プレス品組付け構造のボデーを中心に, 生産工 程と使われる溶接技術について概略を紹介した. 地球温暖 化に対し世界中で環境保護の施策が採られるなかで，身近 な交通手段である，自動車も大きく変わろうとしており， そこで使われる各種材料を組立て，製品とする溶接・接合 技術の重要性は益々増大しているといえる.今後自動車の 溶接分野には多くの方々が係わられると思うが, 本項が少 しでも参考になれば幸いである。

\section{参考文献}

1) トヨ夕の概況 2010, pp.25-26.

2) 田村，近藤：溶接施工管理一自動車，溶接学会誌，Vol.49, No.12, 1980, pp.7-14.

3)「新編 自動車工学便覧」第 6 編車体，自動車技術会， 1983 . 9. 30 .

4)「薄鋼板及びアルミニウム合金板の抵抗スポット溶接」, 溶 接学会軽構造接合加工研究委員会, 2008. 11. 1.

5) 齊藤: 鋼板による車体の軽量化, 車体の軽量化に関するシン ポジューム資料 5 , 溶接学会「車体の軽量化」特別研究会： 1992.2.21.

6) 藤根：自動車の軽量加工技術の動向と課題, 第 256 回塑性加 工シンポジウム資料, 日本塑性加工学会, 2007. 5. 26.

7) H. Tobita, M. Arai, Y. Sibata, H. Muta: Development of flexible production system for body welding, JSAE Review Vol.13, No.1, 1992, pp.76-81.

8）近藤，小西，野村，粉川，合金化溶融亜鉛めっき鋼板と裸鋼 板を混合打点した抵抗スポット溶接の電極消耗変化，溶接 学会論文集, Vol.27, No.4, 2009, pp.352-359.

9) 新井, 井上: ボデー少量生産ラインの構築と新技術, 自動車 技術，Vol.55, No.12, 2001, pp.38-43.

10) 瀬渡:電動加圧式抵抗スポット溶接ガンの適用事例, 溶接学 会誌, Vol.72, No.7, 2003, pp.35-38.

11) 松山: 抵抗溶接用統合型品質保証システムについて, 溶接学 会軽構造接合加工研究委員会資料, MP-441-2008.

12）近藤，小西，野村, 粉川, 合金化溶融亜鉛めっき鋼板の抵抗 スポット溶接における電極先端形状の消耗変化，溶接学会 論文集，Vol.27, No.3, 2009, pp.230-239.

13）定村，戸田，夏見：結合素材によるボデーパネルの一体化, 自動車技術，Vol.48, No.11, 1994, pp.27-32.

14） K. Mann :自動車のボディ製造における高出力固体レー ザ，溶接学会誌，Vol.73, No.8, 2004, pp.19-22.

15）森, 樽井, 長谷川, 吉川：自動車ボディへのリモート溶接技 術の適用, 溶接学会誌, Vol.77, No.3, 2008, pp.11-15.

16) M. Fujimoto, et al.: Friction Spot Joining for Automotive Industry, JAAA2005, pp. 173-180.

17) 佐藤，粉川，藤本：自動車への FSW の適用，溶接技術, Vol.57, No.9, 2009, pp.64-67.

18）恵良，上山：電流波形制御による GMA 溶接のスパッ夕低 減, 溶接学会誌, Vol.75, No.7, 2006, pp.19-23.

19）松井，自動車の溶接・接合技術にかかわる生産現場力，溶接 学会誌, Vol.76, No.1, 2007,pp.17-21. 